\title{
12. Labour market integration of migrants in Germany? ${ }^{1}$
}

\author{
Judith Czepek
}

\subsection{INTRODUCTION: 'IMPORT LABOR BUT NOT PEOPLE'}

Germany had Europe's highest net inflow of refugees in 2015 (Brücker et al., 2017). Like other European governments, Germany is faced with the challenge of governing the integration of migrants successfully. Compared to traditional immigration countries such as Australia, Canada or the United States, Germany has a short but interesting migration history.

This chapter will argue that Germany's migration policy is path dependent as migration history shows great continuity in the degree of state control exerted in responding to employers' labour demands. The demand-driven policy started in the 1950s with the recruitment of low-skilled guest workers. As long as the demand for labour was high and guest workers were expected to return to their home countries (the rotation principle), further integration into society was not considered necessary. This policy continued even though the rotation principle failed as guest workers stayed, formed families and required social infrastructure, such as education and public employment service. Social inequality became increasingly visible, yet calls for the integration of migrants and their children emerged very slowly. Even though the guest workers and their families became a significant part of Germany's population, Germany did not regard itself as an immigration country for a very long time. ${ }^{2}$ From the late 1990s onwards, migration policy has mainly focused on highly skilled workers. Active labour market policies rarely dealt with the specific issues of migrants. Recent changes in migration and labour market policy, however, have taken into account the possibility that migrant workers will stay in Germany. New programmes have addressed deficiencies in language skills, supported workers in obtaining qualifications and facilitated faster access to the German labour market. Germany has learned from its history and some of the newly established programmes in migration and labour policy point in a new direction. 
The structure of the chapter is as follows. Section 12.2 provides an overview of Germany's migration history and policy, describing the different groups of migrants in Germany and presenting the most important regulations applicable to migrants. Section 12.3 examines different institutional barriers for first- and second-generation migrants, such as a segmented labour market and a selective, early track educational system. The review of studies in this section focuses on the determinants of success and failure in the integration of migrants, as measured by wage differences. Additionally, Section 12.3 discusses discrimination against migrants. Section 12.4 examines the potential of active labour market policies to overcome social inequalities in the labour market while Section 12.5 discusses the new measures introduced after 2015. This section also analyses changes in labour and migration administration and the challenges involved in ensuring effective cooperation by the main administrative bodies in charge of the integration of migrants. Section 12.6 concludes with a discussion of the tension between path dependency and new directions in migration and labour market policy and administration in Germany.

\subsection{GERMANY'S MIGRATION HISTORY AND POLICY AS A LABOUR MARKET INSTRUMENT}

According to the German Federal Statistical Office, in 2018 Germany's total population amounted to more than 81 million persons. Individuals with a migration background ${ }^{3}$ accounted for 25.5 per cent of the total. The majority had European roots (65.4 per cent) and most of them came from Turkey, Poland, Former Yugoslavia and the Former Soviet Union (Statistisches Bundesamt, 2019b). The specific ethnic mix is a result of Germany's migration policy and history (Table 12.1).

In the first period after World War II (WWII), many refugees returned to Germany from lands, mainly in Central and Eastern Europe, that had been German territory prior to the end of the war. In 1950, the Federal Republic of Germany counted 9.4 million of those refugees, known as Heimatvertriebene (Lederer, cited in Glorius, 2008: 82). As Germans by descent, following the principle of jus sanguinis, Heimatvertriebene and their offspring are ethnic Germans with an entitlement to German citizenship. ${ }^{4}$ The iron curtain and the reunification of Germany caused two other unique migration inflows: 3.3 million internal refugees left the German Democratic Republic (GDR) for the Federal Republic of Germany (FRG) between 1949 and 1989 (Ammer, 1989; Wendt, 1991) and, based on a law implemented by the Ministerial Council of the GDR, 206,535 Jewish immigrants came to the FRG (Bundesamt für Migration und Flüchtlinge, 2016: 99). 
Table 12.1 Overview of migration policy in Germany from 1954 to 2018

\begin{tabular}{|c|c|}
\hline Year & Significant political events and constitutional changes (timeline of law in force) \\
\hline 1954 & 1951 Refugee Convention (United Nations multilateral treaty) \\
\hline $1955-68$ & $\begin{array}{l}\text { Recruitment agreements (Italy, Spain, Greece, Turkey, Morocco, South Korea, Portugal, } \\
\text { Tunisia, Former Yugoslavia) }\end{array}$ \\
\hline 1958 & $\begin{array}{l}\text { Foundation European Economic Community (EEC) (Belgium, France, Germany, Italy, } \\
\text { Luxembourg, Netherlands) }\end{array}$ \\
\hline 1961 & Construction of the Berlin Wall \\
\hline 1965 & New Aliens Act (replacing the previous law from Nazi Germany from 1938) \\
\hline 1973 & Recruitment stop \\
\hline $1973-86$ & EEC enlargements (Denmark, Ireland, United Kingdom, Greece, Portugal, Spain) \\
\hline 1983 & Repatriation Law \\
\hline 1989 & Fall of the iron curtain \\
\hline \multirow[t]{2}{*}{1992} & Foundation of the EU \\
\hline & 'Asylum compromise', amendment to Asylum Law (safe third country rule) \\
\hline 1993 & Amendment to German Citizenship Law (post-naturalisation for those born in Germany) \\
\hline 1995 & EU enlargement (Austria, Finland, Sweden) \\
\hline 2000 & New Citizenship Law (jus soli by place of birth) \\
\hline $2000-04$ & German Green Card (recruitment programme for highly skilled ICT workers) \\
\hline $2004-13$ & $\begin{array}{l}\text { EU Eastern enlargements (Cyprus, Czech Republic, Estonia, Hungary, Latvia, Lithuania, } \\
\text { Malta, Poland, Slovakia, Slovenia, Bulgaria, Romania, Croatia) }\end{array}$ \\
\hline 2005 & $\begin{array}{l}\text { Immigration Act (replacing the Aliens Act combining regulations regarding residence of } \\
\text { foreigners and resident migrants, and regarding permission to work) }\end{array}$ \\
\hline 2009 & Labour Migration Governance Law (access to labour market for qualified tolerated persons) \\
\hline 2012 & EU Blue Card (for qualified workers of third countries) \\
\hline 2015 & $\begin{array}{l}\text { Amendment of Asylum Law (restrictions: more safe third countries, benefits cuts, and longer } \\
\text { stay in reception centres, but faster application procedures for asylum seekers) }\end{array}$ \\
\hline 2016 & $\begin{array}{l}\text { New Integration Law (removal of barriers for labour market access for asylum seekers (with } \\
\text { good prospects to stay) and recognised asylum seekers, speeding up asylum procedures, } \\
\text { restrictions especially for delinquent asylum seekers) }\end{array}$ \\
\hline 2017 & Amendment of Asylum Law (restrictions in place of residence) \\
\hline 2018 & $\begin{array}{l}\text { Amendment of Asylum Law (recognised refugees are obliged to actively support the review } \\
\text { of their asylum decisions) }\end{array}$ \\
\hline 2019 & $\begin{array}{l}\text { Compact for Migration including various changes in Law (promotion of training and } \\
\text { employment, expansion of entitlements to training, integration courses and vocational } \\
\text { German language courses, restrictions in place of residence, simplified procedure for } \\
\text { deportation) }\end{array}$ \\
\hline
\end{tabular}

Source: Own representation. 
Economic prosperity after WWII created a high demand for low-skilled labour in many Western countries. Between 1955 and 1968, Germany's migration policy was influenced by bilateral recruitment agreements concluded with Italy, Spain, Greece, Turkey, Morocco, Portugal, Tunisia and the Former Yugoslavia. As a second mover, Germany learned from the experiences of other countries and the German government implemented restrictive rights for guest workers and minimised family reunification to ensure only a temporary stay (Castles, 2006: 742). According to the policy of the rotation principle, the first generation was expected to make hardly any demands on the social infrastructure and not to get involved in labour movements (Castles, 1986: 762). As low-skilled workers in the industrial sector, guest workers had low wages and poor working conditions. Castles labelled this policy accurately as 'import labor but not people' (Castles, 2006: 742). With the oil crisis in 1973, the demand for labour decreased and recruitment of guest workers fell following an economic recession. Castles argues that many industries in Europe became dependent on low-cost migrant labour and that the rotation principle was breaking down (Castles, 2006: 743). As the economic recession affected some of the countries of origin even more severely, and there were no prospects for migrants to return, the relatively high incomes and welfare entitlements available in Germany encouraged migrants to seek permanent residence. Most of the guest workers came as young workers and some started families and stayed. As illustrated in Table 12.2, the period of labour migration was followed by one of family reunification and formation. Consequently, migrant families required housing, schooling, health care services and other social infrastructure (Castles, 2006: 743). The theory of a guest worker recruitment system turned out not to be temporary and reversible (Castles, 2006: 743). A consequence of Germany's lack of a response to ethnic diversity with an integration policy was that migrants were treated as 'economically disadvantaged and racially discriminated minorities’ (Castles, 2006: 743).

Guest workers and their families are only one group of migrants with mainly European roots. The establishment of the European Union's (EU) free movement of goods, services and workers was accompanied by a high inflow of refugees, mainly from Former Yugoslavia. After controversial debates, the German government achieved an 'asylum compromise'. The amendment to Asylum Law in 1992 implemented, inter alia, cuts in social benefits for asylum seekers beneath the level of the German resident population, and the 'safe third country rule' (permission to reject asylum seekers of countries of origin declared by government as safe countries to return to). Subsequently, and after the end of the wars in Former Yugoslavia, the previously high inflow of asylum seekers decreased significantly and many refugees returned home. For the next 20 years, refugees were only a minor group. In the meantime, the EU Eastern enlargements stimulated labour migration and the unlimited 


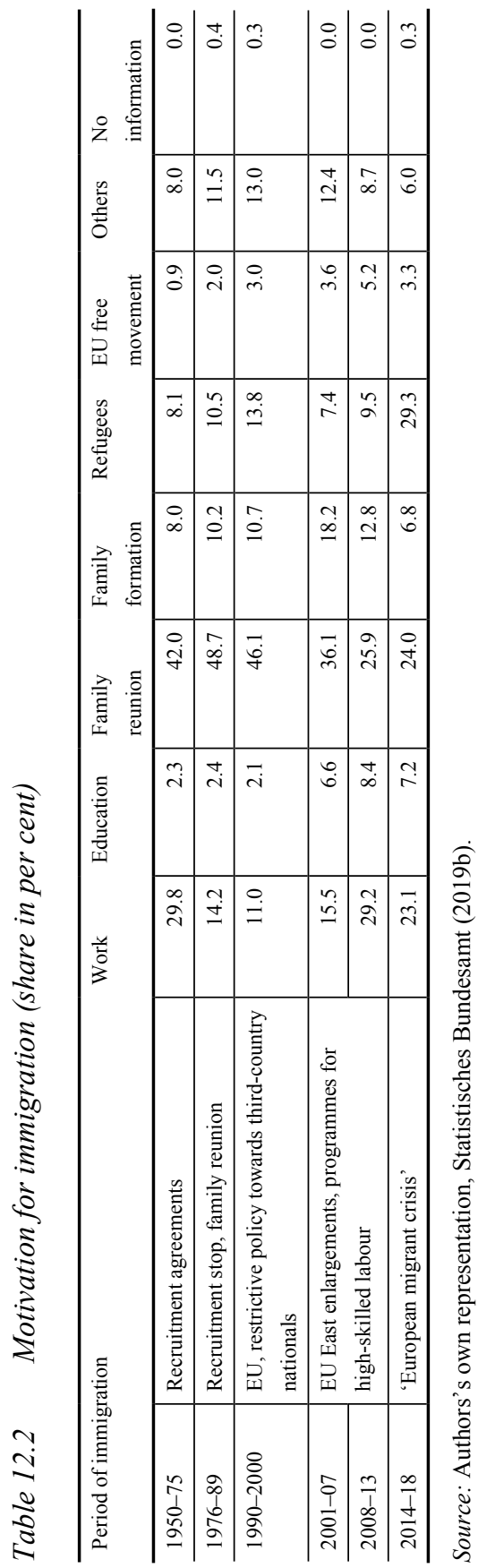


access to the German labour market still constitutes the major inflow of migrants to Germany (Bundesamt für Migration und Flüchtlinge, 2016: 52). Seasonal work (mainly in agriculture) and temporary employment contracts in the construction industry channelled migration from non-EU third countries according to particular labour demands. During this period, these were the only legal routes to the labour market for low-skilled labour migrants from non-EU countries.

Since Germany started recognising itself as an immigration country in 1998, its migration policy has undergone a process of a 'selective liberalisation'. Demographic concerns regarding the consequences of an ageing society and projected labour shortages arose and encouraged the government to implement new policies addressing primarily highly skilled workers. A milestone in Germany's modern migration policy came into force in 2000, when a new Citizenship Law extended, albeit with conditions, German citizenship to people born in Germany but with non-German parents. ${ }^{5}$ Additionally, with the so-called Green Card initiative to attract experts for the information and communication technology (ICT) sector, a second period of demand-driven recruitment policies to attract highly qualified labour began. ${ }^{6}$ The Immigration Act that came into force in 2005 bundled together regulations for migrant residents, EU citizens and non-EU migrants. The Immigration Act was still very restrictive and addressed mainly highly qualified workers from third countries, but German governments relaxed these rules in the following years. ${ }^{7}$ In 2012, the German government introduced the EU Blue Card that applied to highly skilled third-country nationals with low thresholds and it also passed a law to allow people to stay and look for a job for six months; however, this only applied to university graduates earning their own living. Previously, the labour and migration administration demanded an employment contract from applicants for a visa. The 'selective liberalisation' of the German labour migration policy continued by permitting labour market access to qualified workers without a university degree and to those with post-qualification opportunities. Workers in occupations on the so-called Positivliste, ${ }^{8}$ which lists occupations experiencing labour shortages, were granted easier access to the German labour market. Additionally, bilateral recruitment agreements with China, Serbia, Bosnia-Herzegovina, the Philippines and Tunisia allowed for controlled inflows according to labour demands. However, despite these measures, political debates on labour shortages due to high institutional barriers continue (Brücker et al., 2018).

Residence and work permit as prerequisites for access to the German labour market are at the centre of the following considerations. Legal regulations for residence and work permits constitute hard institutional barriers and vary across different groups of migrants and refugees, according to their legal status. Ethnic Germans face few institutional barriers because they are treated as 
Germans and their education and qualifications obtained outside of Germany are recognised (Kogan, 2010: 107). EU citizens enjoy freedom of movement with permanent permissions for residence and work without any legal restrictions. In principle, persons from non-EU countries have to apply for a visa. For those third-country nationals migrating to Germany for work, legal access to temporary residence and work is restricted mainly to highly qualified workers, who must meet requirements regarding education, employment and income. Applicants must await the decision of the Federal Employment Agency. The decision is conditional, for instance to adverse impacts on the labour market (Lehmer and Ludsteck, 2015: 683). Third-country nationals face the greatest hurdles: residence and work are restricted according to their legal status and depend on the reasons for migration (such as work or humanitarian reasons). Migrants arriving in Germany for humanitarian reasons must apply for asylum first. The status of their asylum procedure determines legal regulations on residence and work permit. Arriving asylum seekers ${ }^{9}$ cannot freely choose their place of residence and have to await the final decision of acceptance or rejection of the application. The final decision and duration of the whole process of the application varies across countries of origin (Brenzel and Kosyakova, 2019). Recognised refugees are granted a temporary residence permit (and access to the labour market) and can apply for a permanent residence and work permit after three or five years. ${ }^{10}$ Asylum seekers with pending decisions or tolerated persons (Geduldete are persons with a suspended deportation) can apply for a work permit at a local foreigners' registration offices. Those without a work permit depend on social benefits.

\subsection{DETERMINANTS OF SUCCESS AND FAILURE: BARRIERS FOR MIGRANTS IN THE GERMAN LABOUR MARKET}

'Labour market participation is one of the most important factors of successful integration of immigrants into society' (Pichler, 2011: 939) and the more integrated migrants are in the labour market, the higher their net economic and fiscal contribution to the host country (Algan et al., 2010: 4). However, as shown, Germany has restrictive policies regarding labour market access (such as temporary work permissions, local restrictions for residence). Even with legal access to the labour market, migrants and asylum seekers are confronted with a rigid labour market (Kalter and Granato, 2002; Kogan, 2010) and a highly selective educational system constituting institutional barriers that limit integration for migrants and their descendants, both of which have consequences for wage differentials.

As predicted by human capital theory (Becker, 1975), the impact of education and job experience on wages is strong and migrants with poorer human 
capital resources tend to earn lower wages (Beyer, 2017), although returns to human capital investments vary across countries of origin (Algan et al., 2010: 19-20; Basilio et al., 2017: 247). According to a recent study based on a German socio-economic survey, ${ }^{11}$ irrespective of whether or not the formal educational qualification is the same, migrants still earn 7.3 per cent lower hourly real wages than natives (Beyer, 2017: 14). ${ }^{12}$ Hence, human capital theory explains wage gaps only to a limited extent. Empirical studies agree that insufficient language skills lower wages at the beginning of a migrant's career (Dustmann, 1999; Van Turbergen et al., 2004). Furthermore, the lack of recognition of foreign education and job experience as well as of the transferability of knowledge to the host country lowers wages (Basilio et al., 2017; Beyer, 2017). Assimilation, measured in terms of length of stay, has a positive effect. Newly arrived migrants face on average a wage gap of 21 per cent that decreases over time by around 1 per cent per year, but never completely converges to the level of the natives (Beyer, 2017: 1-16). Overall, results on wage assimilation vary across different groups of migrants and are not so clear-cut for the German case (for an overview see Bauer et al., 2005: 229).

Kogan (2010: 113) investigated the labour market performance of newcomers who had entered Germany since the 1990s and found that better educated migrants tend to get better-quality jobs but face larger wage penalties upon entering work. Wage penalties as systematic disadvantages in pay occur when migrants earn lower wages compared to otherwise equal native workers. For the more recent migrants, Kogan's study pointed to new hurdles: language fluency is more important in highly skilled jobs and good employment prospects often require social networks (Kogan, 2010: 113). Unlike their parents, second-generation migrants have German language skills and have been taught in the same educational system as native Germans and therefore tend to achieve higher educational levels and labour market positions (Kristen et al., 2011; Worbs, 2003). Nevertheless, children of migrants still face significant wage gaps compared to natives by the same generation (Granato and Kalter, 2001: 497). Most children with migrant parents (or with own migration experience before entering school) achieve lower educational levels, tend to be less often in the upper-class track, are more often without training and have worse grades at school than their native German counterparts (Heath et al., 2008; Kristen et al., 2008; Riphahn, 2003).

Boudon (1974) argues that parents' resources have two kinds of effects on educational decisions (for instance to promote tertiary education): Primary effects are based on inequality in competencies and school performance, secondary ones relate to variations across educational decisions given the same school performance. Both effects are stronger in 'streamed', more selective and early track educational systems because the decision for a particular track is made at an early stage and has long-term impacts on educational outcomes, 
such as on degrees, and also on later labour market outcomes. Germany has a selective educational system, with the decision for secondary education made by parents and teachers after only four years of primary schooling. In secondary education, one of three possible levels is chosen, thus determining pathways to labour market entrance. The lower and intermediate levels are followed by a further transition to vocational training. The highest level is the only track leading to entry qualifications for universities and universities of applied sciences. The influence of parental resources to support children's educational success applies to all social groups. Nevertheless, the restrictions in the transferability of parents' foreign education and incomplete information on the educational system in the host country put migrants' children at a disadvantage. Kalter and Granato (2018) note that confidence in securing a return on education investments is lower among migrants, costs are of more significance regarding their educational decisions and they are less likely to invest in higher education (Kalter and Granato, 2018: 361).

Recruited as low-skilled workers and less able to transfer their human capital (Constant and Massey, 2005: 509), migrants of the first generation are channelled into more volatile economic sectors characterised by precarious working conditions, lower wages and a higher risk of unemployment (Kogan, 2004: 447). Second-generation migrants are also trapped in the unstructured segment and face higher risks of unemployment. Kogan (2004) has identified guest workers from Turkey, ethnic Germans and non-EU migrants as having the highest risk of becoming and remaining unemployed (Kogan, 2004: 454). For the second generation, lower educational levels mainly explain a higher risk of unemployment. As for the only migrant group of the second generation, Turks additionally face ethnic penalties (Heath et al., 2008: 220; Kalter and Granato, 2007: 309-10; Kogan, 2010).

The segmented labour market, as an institutional barrier, influences individual labour market behaviour, but with different implications for women and men. Female labour participation highly depends on educational level, household income and the number of children. This applies to both native and foreign-born women; however, migrant women work more often full time and thus compensate for lower wages. In contrast, native mothers tend to work part time due to family circumstances (Dustmann and Schmidt, 2000: 28). Nevertheless, female migrants have a substantial lower participation rate than their native counterparts (Brenzel, 2018).

Migrants' higher probability of entering and remaining in lower wage segments, and of experiencing unemployment, serve as additional explanations regarding the wage gap in a life-course perspective. Remaining unexplained wage differentials are often interpreted as the result of discrimination because discrimination is hard to measure in wage equations. Bartolucci (2014) compared wages of natives and migrants within the same enterprises and found 
that migrants are subject to wage discrimination (Bartolucci, 2014: 1189). Furthermore, Goldberg and Mourinho's (2000: 62) experimental study, which compared young Turkish (second generation) and German testers competing for real job offers, found that 20 per cent of all vacancies remained closed to the Turkish testers because of discrimination.

\subsection{ACTIVE LABOUR MARKET PROGRAMMES AND INTEGRATION PROGRAMMES}

The German welfare state grants migrants and their descendants the same social rights as German nationals (Joppke, 1999: 199). Access to, and the level of, social benefits and social services in Germany depends on place of residence and on labour market participation. The German system has two branches to safeguard unemployed persons' welfare (15 to 67 years old): unemployment benefit (paid at 60 to 67 per cent of previous income) and means-tested basic social assistance with minimum social benefits. Recipients are obliged to engage in active job search and participate in active labour market programmes. Active labour market programmes include, for instance, support in choice of career and qualification, vocational training, promotion and funding for self-employment, subsidies for labour market integration and special measures for social integration of persons with disabilities. These programmes are open to job seekers and sometimes compulsory for recipients of unemployment benefit and social assistance. This applies equally to natives and migrants.

At 38 per cent in June 2018, the proportion of persons with a migration background in the group of unemployed is significantly higher than their share in population in the same year (25.5 per cent) (Bundesagentur für Arbeit, 2019; Statistisches Bundesamt, 2019b). Persons with a migration background are over-represented in both the group of recipients of unemployment benefits and, to an even greater extent, basic social assistance. A lack of qualification and non-recognised foreign qualifications are the most frequently mentioned explanations for the higher rate of unemployment among migrants (Bundesagentur für Arbeit, 2014: 8). At 71 per cent in 2018, the share of unemployed persons with a migration background without any formal qualification is high (Bundesagentur für Arbeit, 2019).

Since the proportion of those without qualifications is much higher among unemployed migrants, one would expect higher participation rates of persons with a migration background in programmes to overcome these disadvantages. However, this is not the case and their participation rate in programmes to support formal qualification is proportional to their unemployment, but not in terms of their lack of qualifications (Bundesagentur für Arbeit, 2018). Poor knowledge of German is not only a barrier to entering the labour market but 
also hinders participation in such programmes (Deeke, 2010: 240). A combined measure of occupational and language training financed by the European Social Fund (ESF) was an exception to promote the labour integration of migrants in Germany from 2000 to 2017. Deeke (2010) found positive effects of the combined occupational and language training programme for the first funding period. However, migrants are less likely than natives to enter the labour market after attending active labour market programmes (Deeke, 2010: 263). In addition to deficiencies in German language skills and non-recognised formal qualifications, Deeke mentions cultural discrimination as a further reason for the lower probability of persons with a migration background, and especially foreigners, entering employment subject to social security contributions (Deeke, 2010: 263-4). In general, active labour market programmes rarely address migrants, in particular because the Federal Employment Agency guarantees equal opportunities and mitigates competition among various groups of job seekers.

However, a policy of social and economic integration through work as implied by channelling migrants according to labour demands confronts difficulties relating to the integration of migrants, including recognition of qualifications, the issue of visa and work permit and integration into employment subject to social security contributions.

Recognition of foreign education is considered crucial for the integration of professionals from abroad (Brücker et al., 2014: 27). In 2012, this was legally specified by the Recognition Act and it has been promoted by a programme that addresses employers as well as potential candidates from around the world to support qualified professionals to come to Germany for work. ${ }^{13}$ In 2013 (before the last inflow of refugees), despite efforts made to support the recognition of foreign qualification, two-thirds of the respondents of the IAB-GSOEP survey ${ }^{14}$ did not apply for a recognition of their foreign qualifications. The interviewees reported that the main reasons for not applying were high costs, time-consuming procedures, a lack of information and that the recognition of their qualifications was not necessary for their employment (Liebau and Romiti, 2014: 19). However, since the Recognition Act has come into force, the number of new applications for professional or occupational recognition has risen continuously (Bundesminsterium für Bildung und Forschung, 2019).

Programmes for the integration of migrants and refugees have also been significantly expanded in the area of political and cultural integration. After the Immigration Act had come into force in 2005, the Federal Office of Migration and Refugees extended its language training programmes. Additionally, civic orientation courses (on Germany's legal system, culture and history) were established for resident migrants, applicants for citizenship, foreign newcomers and asylum seekers. Since 2005, almost 3 million persons have participated in various courses (Bundesamt für Migration und Flüchtlinge, 2019b: 123). 
The Federal Office for Migration and Refugees referred to the participation of voluntary resident migrants in these programmes as 'catching-up integration' (Bundesamt für Migration und Flüchtlinge, 2019b: 122).

\subsection{THE ADMINISTRATION OF LABOUR AND MIGRATION: NEW MEASURES, OLD HURDLES?}

While the integration and qualification of unemployed persons is the task of the Federal Employment Agency, the integration of migrants and refugees arriving in Germany falls within the remit of the integration authorities. Germany has a federal system of labour administration, under the supervision of the Ministry of Labour and Social Affairs. The Federal Employment Agency, its branch offices (Arbeitsagenturen) and local job centres (Jobcenter) are in charge of labour administration. These administrative bodies offer social benefits and services for labour market integration both to natives and migrants, while the integration of migrants and refugees is the responsibility of the Federal Office of Migration and Refugees, which in turn is supervised by the Ministry of the Interior. The recognition of foreign qualifications is an excellent example of overlapping responsibilities between at least three federal government ministries and their subordinate administrative bodies: the Federal Ministry for Employment and Social Affairs and the Federal Employment Agency are responsible for labour market integration and also for defining labour shortages (necessary especially for third-country nationals to get a visa and work permit). The Federal Ministry of the Interior oversees the Federal Office of Migration and Refugees, which is in charge of integration, including civic and language training, which is mandatory for some immigrant groups. These services in training, orientation and integration are provided by accredited local and very often civil society organisations, not by the Federal Office of Migration and Refugees and its local foreigners offices. As a third actor, the Federal Ministry of Education and Research runs a programme to support the recognition of foreign qualifications. In addition, the federal structure in Germany increases the complexity of service provision since the federal states (Länder) have a wide range of responsibilities, for example in education. While the provision of basic social assistance is the responsibility of the job centres and the municipalities (Kommunen) as executive bodies, services to recipients of unemployment benefits (based on social security contributions) are subject to the Federal Employment Agency and its own districts. ${ }^{15}$

More recently, the high inflow of refugees in 2014-16 has led to increasing pressure to bring about legislative and executive changes to promote the integration of migrants. In general, local integration, including social benefits and social services for migrants and refugees, is a task for the federal states and the municipalities. Since 2015, numerous amendments of Asylum Law and a new 
Integration Law have come into force and the Budget Law of 2016 allowed for a massive increase in the budget for labour and migration administration to govern the integration of migrants and refugees. The effort of the federal states and municipalities is governmentally funded with a monthly lump sum of 670 Euro per asylum seeker until the decision on acceptance or rejection of asylum is made. The government also bears the costs for recognised refugees and those granted subsidiary protection, which amounted to 400 million Euro in 2016, increasing to approximately 1,800 million in 2019 (Bundesamt für Migration und Flüchtlinge, 2019a: 27). Additionally, funding is provided for housing (in total about 5.5 billion Euro until 2019). This intervention was not without controversy, as it was interpreted as federal interference in the responsibilities of the federal states and municipalities. At the same time, the burden on the federal states and local authorities could not be dealt with without financial support from the federal government. The discussion about the financial transfers was accompanied by a controversy regarding the question of how the arriving refugees should be distributed.

The so-called Asylum Treaties I and II that came into force in 2016 consist of various legal regulations and administrative measures to speed up asylum procedures. These include changes in electronic data exchange to ensure a fast and safe registration and communication between the different responsible administrative bodies. As many stakeholders are involved, cooperation and bundling competencies were a priority. In so-called reception centres (Ankunftszentren), incoming refugees are obliged to stay and await the decision of acceptance or rejection of the application for asylum. The reception centres offer accommodation and support during the whole asylum process: following the first registration (collection of personal and biographical data, identity check), this includes the whole process of application for asylum (application, hearings and decision) by the Federal Office for Migration and Refugees, medical examination and care provided by the federal states and initial counselling on labour market access by local job centres. While the responsibility for the provision of services remains with the local authorities, the competence and resources of the federal authorities have been expanded. As part of the new administrative structure, the Federal Office for Migration and Refugees and the Federal Employment Agency have collaborated more closely. The culmination was that the former CEO of the Federal Employment Agency Frank-Jürgen Weise agreed to combine two managerial functions and to direct additionally the Federal Office for Migration and Refugees in the years 2015-16. Human resources at the Federal Office for Migration and Refugees increased substantially, from 3,000 employees in 2015 to 7,300 in the following year. Furthermore, 3,100 employees were delegated mainly from the Federal Employment Agency to temporary support integration (Bundesamt für Migration und Flüchtlinge, 2019a: 15). 
This 'integrated refugee management' involves all responsible authorities and shows the improvement in cooperation between the administrative bodies to bundle competencies and to speed up asylum procedures. With the new regulations, fast-track asylum procedures should take only one week for decision-making and another week for court order. Final and fast decision on the legal status are important because permissions for temporary residence, access to integration and language training, labour market integration and work permits depend on the officially awarded prospects of the refugees to remain in Germany (Bleibeperspektive). This has consequences for the administrative bodies, their partners, the refugees and also the employers, who are only allowed to employ people with prospects of remaining in Germany. Since 2015, migration policy and integration efforts have differed sharply in orientation, following the crucial distinction between those with good prospects to remain in Germany and those for whom such prospects do not exist. Refugees from countries other than Eritrea, Iraq, Iran, Syria and Somalia and with acceptance rates below 50 per cent in previous asylum procedures have no access to programmes which support integration and which are prerequisites for entering the labour market. For those with good prospects to stay in Germany, existing integration courses have been expanded to improve civic education and language skills. However, tighter restrictions have also been implemented, such as a tightening of family reunification and an easier deportation for rejected asylum seekers.

Different institutions such as the European Social Fund (ESF), the Federal Ministry of Labour and Social Affairs or the Federal Ministry of the Interior promote programmes to facilitate fast labour market integration for migrants with good prospects to remain in Germany. Various work-related language programmes combine language and vocational training. The diversity of the level of qualification and alphabetisation requires tailor-made offers that vary from introductory to few courses for the highly educated and address various social groups such as low-skilled refugees or women (OECD, 2017: 13). KompAS or KomBEer, for instance, are shared programmes, which combine the integration course of the Federal Office of Refugees and Migration with activation and qualification measures of the Federal Employment Agency. The Federal Employment Agency and the local job centres collect information on existing qualifications, and provide information to find adequate measures. Training and educational programmes are contracted to providers, namely the social partners and other providers of training services (Jantz and Klenk, 2015: 107-8).

A study based on a recent refugee survey ${ }^{16}$ reports that in 2017,75 per cent of the surveyed refugees participated in or completed a language course, 9 per cent of them attended a work-related programme, and an additional 12 per cent participated to the KompAS programme (Brücker et al., 2019: 4-5). Most of 
the newly arrived migrants had no German language skills. After completing a language course, 52 to 71 per cent (depending on the provider) of participants reported good or very good skills in German (Brücker et al., 2019: 6).

New regulations facilitate earlier access into the labour market and support for labour market integration; however, these regulations are restricted to asylum seekers with good chances to stay in Germany and apply only temporarily. Since legal certainty is a key issue reported by employers (OECD, 2017: 12), the ' $3+2$-rule' guarantees (under certain conditions) the completion of an apprenticeships including two following years in employment for refugees with temporary residence permit or for asylum seekers who are rejected during their apprenticeship. To reduce barriers to enter the labour market, the priority check to protect employment of residents has been temporarily abandoned in some regions in Germany and easier access to temporary employment services promotes job opportunities for refugees. Additionally, the German government introduced funded employment. The programme offers 100,000 job opportunities, created and publicly funded to open a low threshold entry into the German labour market (Bundesamt für Migration und Flüchtlinge, 2019a: 30).

Since the German labour market is strongly segmented and barriers to enter better positions in qualified work are high, the successful labour market integration of migrants is strongly linked to language skills and qualification. However, most programmes aim at the rapid and not necessarily long-term integration of migrants and refugees into the labour market. Therefore, these new regulations may channel migrants and refugees into low-skilled jobs in volatile labour market sectors, where their fortunes will depend heavily on the current economic situation. At present, the integration of migrants in the German labour market benefits from relatively good economic conditions. However, this may change and therefore continuing support will be necessary for long-term integration (OECD, 2017: 26). Finally, an adequate labour migration policy calls for a long-term view matching qualifications and residence according to meet labour demands, as immense regional differences characterise the German labour market and labour shortages occur mainly in occupations that require vocational training (Czepek et al., 2015: 46).

The previous section has shown that labour and migration administration is not only costly if external demands require political action, but the new situation that arose in 2014-16 also challenges the federal system in Germany. Governmental funding and certain regulations as well as services provided are granted on temporary and selective bases. The implementation of so-called reception centres was seen as the main solution to pool the demands of the incoming refugees for social benefits and social services. Both the labour and migration administration took advantage of new technologies to collect and connect information about the refugees to speed up the decision-making process during the asylum procedure. This was also necessary because the 
benefits of various programmes are only open to those with declared good prospects to stay. Ongoing challenges are the cooperation and coordination of different actors such as administrative authorities, public and private service providers and social partners in a federal system with established responsibilities. At the same time, bureaucratic hurdles have to be reduced in order to achieve the political goal of a successful integration (into the labour market).

\subsection{CONCLUSION: PATH DEPENDENCY BUT LESSONS LEARNED}

Germany's migration policy shows great continuity in answering labour demands. After WWII, guest worker recruitment agreements met the high demand for low-skilled labour. The bilateral agreements were followed by the EU agreement on the free movement of goods, services and labour. Since the EU single market has been established, Germany's migration policy has combined an unlimited inflow of EU internal migration with restrictive policies for non-EU nationals to control migration inflows according to labour demands. At the end of the 1990s, debates on the consequences of an ageing society and upcoming labour shortages led to a strategy of a 'selective liberalisation' accompanied with tailored programmes to attract highly skilled workers.

Recently, Germany and other receiving countries have faced an immense challenge to govern the high inflow of migrants. From a path dependency perspective, the so-called 'European migrant crisis' in 2015-16 can be interpreted as a critical juncture, a moment for institutional change when external events put pressure on the existing institutional arrangement. Such situations of external pressure and changing environments create new conditions for existing institutions and make radical change or at least a wide range of adjustments of legislative regulations or executing organisations more likely. However, Germany continued its restrictive policy with high state control of migration inflows and passed even more legislative regulations with various amendments in Asylum Law including, for instance, an obligation in place of residence and more safe third countries to reject asylum seekers.

Following the path dependency approach, Pierson (2004) argues that both public policies and political institutions are resistant to change because political actors create long-lasting rules, bind themselves in commitments and formal barriers to institutional reform are extremely high (Pierson, 2004: 43). In Germany, continuity in migration policy is a result of a consensus-oriented political system with a federal structure including overlapping responsibilities. Such characteristics of the political system make institutional changes, for instance of legislative regulations in responsibilities or executive collaborations, even more difficult. Thus, institutional change requires compromises, coalition building and learning effects. 
Germany's recent migration policy is characterised by such political compromises, coalition building and learning effects. Coalitions include political parties, various interest groups and the social partners. Representatives of employer's organisations and unions participate in committees during the legislative process and both are represented on advisory boards in administrative bodies in Germany. Finding a balance in migration and labour market policy between various interest groups is challenging. While union-affiliated forces express concerns about an intensified competition that may lower wages and increase unemployment, employer-friendly representatives speak of labour shortages and restrictive, inflexible labour markets. The good prospects of staying criterion works as a political compromise for political parties and the social partners, because this crucial distinction to provide support and easier labour market access only to those likely to remain in Germany reduces uncertainty for employers and employees. At the same time, the restrictive migration and labour market policy limits inflows from West Balkan countries and other third countries as these refugees have no declared prospects of staying. New regulations continue the strategy of a selective liberalisation to attract the required professionals for the labour market. Hence, the agreement reached also meets the interests of both the Federal Ministry of the Interior for more control and the Federal Ministry of Labour and Social Affairs for rapid labour market integration.

However, this political compromise is moreover a result of learning effects from migration history (as discussed in Section 12.2). The guest workers' policy was based on the rotation principle, assuming that labour migrants would mostly return home afterwards. However, the rotation principle failed as the guest workers stayed, formed families and became a significant part of Germany. The continuity of institutional barriers that still hinder a successful integration is observable in hurdles to get legal access to the labour market, to gain better-qualified jobs in a segmented labour market and to achieve higher education in a selective educational system (as discussed in Section 12.3). The mostly non-tailored active labour market programmes (as shown in Section 12.4) have not been sufficient to overcome social inequality and limited social mobility. Persisting social inequality hinders migrants' equal participation in the labour market for future generations as well. Pichler labels this blocked social mobility as 'segmented assimilation' (Pichler, 2011: 943).

Since 2015, Germany's migration policy has emphasised the importance of qualifications and adequate German language skills and took major steps as learning effects resulted in new regulations to support vocational training and German language skills to facilitate rapid labour market integration. Lessons have been learned in labour market policies with regard to investment in the human capital of unqualified workers through vocational training programmes and apprenticeships. New regulations allow for low threshold labour 
market entrance with internships and publicly funded 'job opportunities'. Additionally, integration is being promoted by compulsory orientation courses for civic education and language training programmes. The German path of institutional change can be described with reference to Streeck and Thelen (2005), who argue that gradual institutional change is most likely as it implies only incremental modifications by building on existing institutions and attaching new elements (Streeck and Thelen, 2005: 18-30).

In view of the United Nations' (UN) 11 principles for effective governance for sustainable development, recent policy changes in Germany point to an expansion of horizontal and vertical collaborations. The expansion can be observed across various levels as the coordination of the inflow of refugees and the integration management required cooperation between both political parties in government and the two Federal Ministries (Federal Ministry of Interior and the Federal Ministry of Labour and Social Affairs) and their subordinated administrative bodies. This also included staff mobility to support fast procedures and integration. Vertical collaborations appear for instance in transparent, huge financial transfers that provide funding from the federal levels to the federal states and to the municipalities. The transfer of resources also involves an extension of the actual competences on the local level. Horizontal and vertical cooperation and monitoring is driven by technology as new regulations allow for, and technical infrastructure supports, data collection and shared use of information. Independent oversight is provided by courts reviewing administrative decisions, for instance in asylum procedures. However, the high inflow and the haste of decision-making represents a challenge for judicative bodies. To leave no one behind, the reception centres were established to offer accommodation and support during the whole asylum process. However, regulations applying to the varying legal statuses of migrants, refugees or asylum seekers cause inequality and access to support depends on the country of origin and the declared prospects to stay in Germany (as discussed in Section 12.5).

The federal states and municipalities are currently bearing the greatest burden of responsibility for integrating the recent migrants. The government is therefore supporting existing structures by providing very substantial financial resources for integration. The financial transfers to the municipalities and civil society organisations mean that the agencies take more responsibility and their obligation to distribute the funds leads to a shift from the legislative to the executive bodies. In addition, the new federal legislation, which interferes with the responsibilities of the federal states, gives more leeway to the federal states. Consequently, regional differences in the integration of migrants and refugees are increasing.

Despite gradual institutional changes, continuity is predominant in three dimensions: Firstly, in the definition of political objectives, such as to focus 
integration primary on a fast and low threshold labour market access. Secondly, the emphasis on the prospects to remain in Germany allows continuing restrictive policies against those without these officially awarded chances. However, this alignment in most of the new regulations and programmes points to a new direction to accept the high probability that some refugees will remain in Germany permanently. Thirdly, on the organisational level the federal structure and overlapping responsibilities have not changed but have created a high demand for coordination. The new measures going beyond the existing policy instruments can be interpreted as lessons learned from policy evaluation and the history of migration in Germany. The new direction in labour market and migration policies means accepting that refugees may stay and, if so, have to be integrated sufficiently.

\section{NOTES}

1. The author thanks Hanna Brenzel, Marie-Pier Joly, Jason Heyes and Ludek Rychly for valuable comments, Lucie Hamdi for linguistic proofreading and Hequn Wang for her helpful assistance.

2. Initiated by the new government in 1998 , debates on reforming citizenship and immigration started.

3. Persons with a migration background have either their own migration experience or have migrated parents living in the same household.

4. New frontiers established during the Cold War left a large number of ethnic Germans behind (Glorius, 2008: 82). Before 1990, regulation procedures in order to facilitate remigration were less restrictive and 2 million ethnic Germans, mostly from Poland, returned to Germany between 1950 and 1990 (Bundesverwaltungsamt, 2018, 2019). After the fall of the iron curtain, a new formal recognition process restricted legal entry to those with preliminary permission. The inflow from 1991 to 2018 was 2.5 million (Bundesverwaltungsamt, $2018,2019)$; this constitutes a significant decrease after the end of the Cold War with the majority of ethnic Germans and their family members coming from the Former Soviet Union.

5. For a long time, German citizenship had only been defined by descent; for example, one or both parents are German citizens (Latin: jus sanguinis) and not by place of birth. Thus, migrants from Russia with German ancestors are ethnic Germans with a German citizenship, while children of guest workers born in Germany have for example Turkish citizenships (Algan et al., 2010: 7). Award of German citizenship had been very restrictive until an amendment to Aliens Act came into force in 2000. Afterwards, German citizenship was also available to migrants who had lived in Germany for a long time and had sufficient knowledge of German and an income allowing a life without social benefits. 'Since 2000, children born in Germany to foreign parents acquire German citizenship at birth in addition to the foreign citizenship of their parents, on the principle of jus soli (Latin for "right of the territory"). At least one of their parents must have been a legal resident of Germany for at least eight years and must have a permanent right of residence at the time of the child's birth' (Bundesministerium des Inneren 2019). Multiple citizenships are mainly restricted to citizens of EU member states 
and Switzerland. In 2018, 109,204 people became German citizens via naturalisation (Statistisches Bundesamt 2019a).

6. The programme (2000-04) was less successful than expected and only 17,658 approvals instead of the targeted 20,000 German Green Cards were granted during its term (Bundesamt für Migration und Flüchtlinge, 2004, 2006).

7. The Immigration Act mainly addressed highly qualified people such as researchers and professionals with long-term prospects. Access to the labour market was reserved for those with employment contracts and very high income (at least twice the assessment ceiling for contributions to statutory health insurance; an income of more than 80,000 Euro per year in 2005). For the self-employed, a certain minimum of investments and at least ten new hires were required. Additionally, the Immigration Act stipulated a temporary 18-month work permit for foreign students. With the lower restrictions, passed in the meantime, highly qualified people have to earn at least 50,800 Euro per year (or 39,624 Euro for occupations with declared labour shortages on the so-called Positivliste) (Blue Card, 2019).

8. The occupations on the so-called Positivliste include scientists, mathematicians, engineers, medical doctors (except dentists) and ICT professionals.

9. Following change in the law in 2016, even recognised refugees are not free in choosing their place of residence if they are not able to earn their own living.

10. Inter alia depending on the proof of language skills and sufficient resources to cover the cost of living (subsistence).

11. The German Socio-Economic Panel (GSOEP) is a representative longitudinal panel study of private households with around 30,000 respondents per year. For further information, please visit: https://www.diw.de/en/diw_02.c.299771.en/ about_soep.html, accessed 31 August 2021.

12. Controls include age, region, family status, full or part-time work, years worked in a company and industrial sector.

13. For further information, please visit: https://www.make-it-in-germany.com/en/ jobs/recognition/professional-qualifications/, accessed 31 August 2021.

14. The IAB-GSOEP migration sample is a household survey with four waves carried out from 2013 to 2016. In 2013, the survey included around 2,700 households with at least one person who had immigrated either to Germany since 1994 or whose parents had done so. For further information, please visit: https://fdz.iab.de/en/ FDZ_Individual_Data/iab-soep-mig.aspx, accessed 31 August 2021.

15. In migration issues, the responsibilities additionally depend on the legal status of the migrants and refugees. The Federal Employment Agency, even though funded by social security contributions, is in charge during the asylum process, while the job centres provide the services for recognised refugees and tolerated persons as social benefit recipients without a working permit.

16. The IAB-BAMF-GSOEP survey is a household panel study. The sample is based on administrative data of the Central Foreigners' Register. In 2017, 5,544 persons were surveyed, 2,630 of them having already participated in the first wave conducted in 2016.

\section{REFERENCES}

Algan, Y., Dustmann, C., Glitz, A., and Manning, A. (2010), 'The economic situation of first and second-generation immigrants in France, Germany and the United Kingdom', The Economic Journal, 120 (542), 4-30. 
Ammer, T. (1989), 'Stichwort: Flucht aus der DDR', Deutschland-Archiv, 22, 1206-8.

Bartolucci, C. (2014), 'Understanding the native-immigrant wage gap using matched employer-employee data: Evidence of Germany', Industrial and Labor Relations Review, 67 (4), 1166-202.

Basilio, L., Bauer, T. K., and Kramer, A. (2017), 'Transferability of human capital and immigrant assimilation: An analysis for Germany', Labour, 31 (3), 245-64.

Bauer, T. K., Dietz, B., Zimmermann, K. F., and Zwintz, E. (2005), 'German migration: Development, assimilation, and labour market effects', in Klaus F. Zimmermann (ed.), European Migration: What Do We Know?, Oxford: Oxford University Press, pp. 197-261.

Becker, G. S. (1975), Human capital: A theoretical and empirical analysis, with special reference to education, 2nd edition, New York: Columbia University Press.

Beyer, R. C. M. (2017), 'The performance of immigrants in the German labor market', SOEP papers, 892, Berlin: German Institute for Economic Research (DIW).

Blue Card (2019), Blue Card EU for Germany, accessed 7 November 2019 at http:// www.bluecard-eu.de/eu-blue-card-german.

Boudon, R. (1974), Education, opportunity, and social inequality: Changing prospects in western society, New York, London, Sydney and Toronto: John Wiley \& Sons.

Brenzel, H. (2018), Economic integration of migrants in Germany, Bielefeld: Bertelsmann.

Brenzel, H. and Kosyakova, Y. (2019), 'Geflüchtete auf dem deutschen Arbeitsmarkt: Längere Asylverfahren verzögern Integration und Spracherwerb’, IAB-Kurzbericht, 06.2019, Nuremberg: Institute for Employment Research (IAB).

Brenzel, H. and Reichelt, M. (2018), 'Job mobility as a new explanation for the immigrant-native wage gap: A longitudinal analysis of the German labor market', The International Migration Review, 52 (3), 724-49.

Brücker, H., Tucci, I., Bartsch, S., Kroh, M., Trübswetter, P., and Schupp, J. (2014), 'Auf dem Weg nach Deutschland: Neue Muster der Migration', in Die IAB-SOEP-Migrationsstichprobe: Leben, lernen, arbeiten - wie es Migranten in Deutschland geht, IAB-Kurzbericht, 21.1, Nuremberg: Institute for Employment Research (IAB), pp. 3-12.

Brücker, H., Hauptmann, A., and Sirries, S. (2017), 'Zuzüge nach Deutschland', Aktuelle Berichte, 1 (2017), Nuremberg: Institute for Employment Research (IAB).

Brücker, H., Hauptmann, A., and Vallizadeh, E. (2018), 'Fachkräfteeinwanderung aus Drittstaaten: Zum Eckpunktepapier der Bundesregierung', IAB-Stellungnahme, 9, Nuremberg: Institute for Employment Research (IAB).

Brücker, H., Croisier, J., Kosyakova, Y., Kröger, H., Pietrantuono, G., Rother, N., and Schupp J. (2019), 'Zweite Welle der IAB-BAMF-SOEP-Befragung: Geflüchtete machen Fortschritte bei Sprache und Beschäftigung', IAB-Kurzbericht, 03.2019, Nuremberg: Institute for Employment Research (IAB).

Bundesagentur für Arbeit (2014), 'Der Arbeitsmarkt in Deutschland Menschen mit Migrationshintergrund auf dem deutschen Arbeitsmarkt', Arbeitsmarktberichterstattung Juni 2014, Nuremberg: Bundesagentur für Arbeit.

Bundesagentur für Arbeit (2018), 'Migrationshintergrund nach $§ 281$ Abs. 2 SGB III', Arbeitsmarkt in Zahlen März 2018, Nuremberg: Bundesagentur für Arbeit.

Bundesagentur für Arbeit (2019), 'Migrationshintergrund nach § 281 Abs. 2 SGB III', Arbeitsmarkt in Zahlen Juni 2019, Nuremberg: Bundesagentur für Arbeit.

Bundesamt für Migration und Flüchtlinge (2004), Bericht des Sachverständigenrates für Zuwanderung und Integration im Auftrag der Bundesregierung in Zusammenarbeit mit dem Europäischen Forum für Migrationsstudien (efms) an der Universtität 
Bamberg, Nuremberg: Bundesamt für Migration und Flüchtlinge, accessed 15 February 2019 at http://www.bamf.de/SharedDocs/Anlagen/DE/Publikationen/ Migrationsberichte/migrationsbericht-2004.html.

Bundesamt für Migration und Flüchtlinge (2006), 'Bericht 2005 über Migration und Asyl an die EG-Kommission', Nuremberg: Nationaler Kontaktpunkt Deutschland im Europäischen Migrationsnetzwerk (EMN), Nuremberg: Bundesamt für Migration und Flüchtlinge.

Bundesamt für Migration und Flüchtlinge (2016), Migrationsbericht des Bundesamtes für Migration und Flüchtlinge im Auftrag der Bundesregierung: Migrationsbericht 2015, Nuremberg: Bundesamt für Migration und Flüchtlinge, accessed 15 February 2019 at http://www.bamf.de/SharedDocs/Anlagen/DE/Publikationen/ Migrationsberichte/migrationsbericht-2015.html.

Bundesamt für Migration und Flüchtlinge (2019a), Migrationsbericht des Bundesamtes für Migration und Flüchtlinge im Auftrag der Bundesregierung: Migrationsbericht 2016-2017, Nuremberg: Bundesamt für Migration und Flüchtlinge, accessed 15 February 2019 at https://www.bamf.de/SharedDocs/Anlagen/DE/Publikationen/ Migrationsberichte/migrationsbericht-2016-2017.html?nn=1362958.

Bundesamt für Migration und Flüchtlinge (2019b), Das Bundesamt in Zahlen 2018 - Asyl, Migration und Integration, Nuremberg: Bundesamt für Migration und Flüchtlinge, accessed 12 December 2019 at https://www.bamf.de/SharedDocs/ Anlagen/DE/Statistik/BundesamtinZahlen/bundesamt-in-zahlen-2018.pdf?_blob= publicationFile\&v $=14$.

Bundesministerium des Inneren (2019), Obligation to choose one citizenship, accessed 12 December 2019 at https://www.bmi.bund.de/EN/topics/migration/obligation-one -citizenship/obligation-one-citizenship-node.html.

Bundesministerium für Bildung und Forschung (2019), Bericht zum Anerkennungsgesetz 2019, accessed 18 December 2019 at https:/www.bmbf.de/files/BzA19 _Vorabfassung\%20final_Akteursgrafik.pdf.

Bundesverwaltungsamt (2018), (Spät-)Aussiedler und ihre Angehörigen Zeitreihe 1950 - 2017: Herkunftsstaaten, accessed 12 September 2018 at https://www.bva.bund .de/SharedDocs/Downloads/DE/Buerger/Migration-Integration/Spaetaussiedler/ Statistik/Zeitreihe_1950_2017.pdf?_blob=publicationFile\&v=4.

Bundesverwaltungsamt (2019), (Spät-)Aussiedler und ihre Angehörigen Zeitreihe 1992 - 2018: Herkunftsstaaten ehemalige Sowjetunion, accessed 12 December 2019 at https://www.bva.bund.de/SharedDocs/Downloads/DE/Buerger/Migration -Integration/Spaetaussiedler/Statistik/Zeitreihe_1992_2018_SES.pdf?_blob= publicationFile \& $\mathrm{v}=6$.

Castles, S. (1986), 'The guest-worker in western Europe: An obituary', The International Migration Review, 20 (4), 761-78.

Castles, S. (2006), 'Guestworkers in Europe: A resurrection?', The International Migration Review, 40 (4), 741-66.

Constant, A. and Massey, D. S. (2005), 'Labor Market Segmentation and the Earnings of German Guestworkers', Population Research and Policy Review, 24 (5), 489-512.

Czepek, J., Dummert, S., Kubis, A., Leber, U., Müller A., and Stegmaier J. (2015), Betriebe im Wettbewerb um Arbeitskräfte. Bedarf, Engpässe und Rekrutierungsprozesse in Deutschland, Bielefeld: Bertelsmann.

Deeke, A. (2010), Arbeitsmarktpolitik mit dem europäischen Sozialfonds: Ergänzung des SGB III aus Mitteln des ESF: Umsetzung und Wirkungen, Bielefeld: Bertelsmann.

Dustmann, C. (1999), 'Temporary migration, human capital, and language fluency of migrants', The Scandinavian Journal of Economics, 101 (2), 297-314. 
Dustmann, C. and Schmidt, C. M. (2000), 'The wage performance of immigrant women: Full-time jobs, part-time jobs, and the role of selection', IZA Discussion Paper, 233, Bonn: Institute of Labor Economics (IZA).

Glorius, B. (2008), 'Report from Germany', in Jeroen Doomernik and Michael Jandl (eds), Modes of migration regulation and control in Europe, Amsterdam: Amsterdam University Press, pp. 81-104.

Goldberg, A. and Mourinho, D. (2000), 'The occurrence of discrimination in Germany', in Roger Zegers de Beijl (ed.), Documenting discrimination against migrant workers in the labour market. A comparative study of four European countries, Geneva: ILO, pp. 53-63.

Granato, N. and Kalter, F. (2001), 'Die Persistenz Ethnischer Ungleichheit auf dem deutschen Arbeitsmarkt. Diskriminierung oder Unterinvestition in Humankapital?', Kölner Zeitschrift für Soziologie und Sozialpsychologie, 53 (3), 497-520.

Heath, A. F., Rothon, C., and Kilpi, E. (2008), 'The second generation in Western Europe: Education, unemployment, and occupational attainment', Annual Review of Sociology, 34, 211-35.

Jantz, B. and Klenk, T. (2015), 'Marketization and managerialization of active labour market policies in a comparative perspective', in Tanja Klenk and Emmanuele Pavolini (eds), Restructuring welfare governance. Marketization, managerialism and welfare state professionalism, Cheltenham, UK and Northampton MA, USA: Edgar Elgar Publishing, pp. 97-117.

Joppke, C. (1999), Immigration and the Nation-State. The United States, Germany, and Great Britain, Oxford and New York: Oxford University Press.

Kalter, F. and Granato, N. (2002), 'Demographic change, educational expansion, and structural assimilation of Immigrants: The case of Germany', European Sociological Review, 18 (2), 199-216.

Kalter, F. and Granato, N. (2007), 'Educational hurdles on the way to structural assimilation in Germany', in Anthony F. Heath and Sin Yi Cheung (eds), Unequal chances: Ethnic minorities in western labour markets, Oxford: Oxford University Press, pp. 271-319.

Kalter, F. and Granato, N. (2018), 'Migration und ethnische Ungleichheit auf dem Arbeitsmarkt', in Martin Abraham und Thomas Hinz (eds), Arbeitsmarktsoziologie, Wiesbaden: Springer, pp. 355-87.

Kogan, I. (2004), 'Last hired, first fired? The unemployment dynamics of male immigrants in Germany', European Sociological Review, 20 (5), 445-61.

Kogan, I. (2010), 'New immigrants: Old disadvantage patterns? Labour market integration of recent immigrants into Germany', International Migration, 49 (1), 91-117.

Kristen, C., Reimer, D., and Kogan, I. (2008), 'Higher education entry of Turkish immigrant youth in Germany', International Journal of Comparative Sociology, 49 (2-3), 127-51.

Kristen, C., Edele, A., Kalter, F., Kogan, I., Schulz, B., Stanat, P., and Will, G. (2011), 'The education of migrants and their children across the life course', Zeitschrift für Erziehungswissenschaft, 14, 121-37.

Lehmer, F. and Ludsteck, J. (2015), 'Wage assimilation of foreigners: Which factors close the gap? Evidence from Germany', Review of Income and Wealth, 61 (4), $677-701$.

Liebau, E. and Romiti, A. (2014), 'Bildungsbiografien von Zuwanderern nach Deutschland: Migranten investieren in Sprache und Bildung', in Die IAB-SOEP-Migrationsstichprobe: Leben, lernen, arbeiten - wie es Migranten in 
Deutschland geht, IAB-Kurzbericht, 21.2, Nuremberg: Institute for Employment Research (IAB), pp. 13-20.

OECD (2017), Finding their Way. Labour market integration of refugees in Germany, accessed 15 February 2019 at https://www.oecd.org/els/mig/Finding-their-Way -Germany.pdf.

Pichler, F. (2011), 'Success on European labor markets: A cross-national comparison of attainment between immigrant and majority populations', The International Migration Review, 45 (4), 938-78.

Pierson, P. (2004), Politics in time. History, institutions, and social analysis, Princeton and Oxford: Princeton University Press.

Riphahn, R. T. (2003), 'Cohort effects in the educational attainment of second-generation immigrants in Germany: An analysis of census data', Journal of Population Economics, 16 (4), 711-37.

Statistisches Bundesamt (2019a), 'Bevölkerung und Erwerbstätigkeit: Einbürgerungen', Fachserie 1 Reihe 2.1, accessed 12 December 2019 at https://www.destatis.de/ DE/Themen/Gesellschaft-Umwelt/Bevoelkerung/Migration-Integration/Publikation en/Downloads-Migration/einbuergerungen-2010210187004.pdf?_blob=publica tionFile.

Statistisches Bundesamt (2019b), 'Bevölkerung und Erwerbstätigkeit: Bevölkerung mit Migrationshintergrund: Ergebnisse des Mikrozensus 2018', Fachserie 1 Reihe 2.2, accessed 12 December 2019 at https://www.destatis.de/DE/Themen/Gesellschaft -Umwelt/Bevoelkerung/Migration-Integration/Publikationen/Downloads-Migration /migrationshintergrund-2010220187004.pdf? blob=publicationFile.

Streeck, W. and Thelen, K. (2005), 'Introduction: Institutional change in advanced political economies', in Wolfgang Streeck and Kathleen Thelen (eds), Beyond continuity. Institutional change in advanced political economies, New York: Oxford University Press, pp. 1-39.

Van Turbergen, F., Maas, I., and Flap, H. (2004), 'The economic incorporation of immigrants in 18 Western societies: origin, destination, and community effects', American Sociological Review, 69, 704-27.

Wendt, H. (1991), 'Die deutsch-deutschen Wanderungen', Deutschland-Archiv, 24, 386-95.

Worbs, S. (2003), 'The second generation in Germany: between school and labor market', The International Migration Review, 37 (4), 1011-38. 